centroids of the $\mathrm{Cp}$ rings are 2.388 [6] $\AA$ from the $\mathrm{Y}$ atoms, but the $\mathrm{Cp}$ planes are not perpendicular to the $\mathrm{Y}-\mathrm{Cp}$ vectors. $\mathrm{Y}-\mathrm{C}(\mathrm{Cp}$ ring $)$ distances range from 2.585 (5) to 2.817 (6) $\AA$, with the $\mathrm{C}$ atoms closest to the Si bridge being closest to Y. This effect is caused by the bridging $\mathrm{Si}$ atom; it 'pinches' the $\mathrm{Cp}$ rings together and the $Y$ atom can no longer fit between them perfectly. This effect is also seen in the angle between the two $\mathrm{Cp}$ planes: this is $113(4)^{\circ}$, whereas the $\mathrm{Cp} 1-\mathrm{Y}-\mathrm{Cp} 2$ angle is $122.3^{\circ}$. (The $\mathrm{Cp}(\mathrm{C})-\mathrm{Sil}-\mathrm{Cp}(\mathrm{C})$ angle is $99.3[3]^{\circ}$.\} Other distances in the $\mathrm{Y}$ molecule are normal: $\mathrm{Y}-\mathrm{Cl}$ 2.627 [12], $\mathrm{Si}-\mathrm{C} 1.863$ [12], $\mathrm{C}-\mathrm{C}$ ( $\mathrm{Cp}$ rings) $1.422[17] \AA$. In each molecule there is a strain evidenced by two normal $\mathrm{C}(\mathrm{Cp})-\mathrm{Si}-\mathrm{CH}_{3}$ angles of $108.4[4]^{\circ}$ and a third larger angle of $117.0[10]^{\circ}$, to the methyl $\mathrm{C}$ atom near the other $\mathrm{Cp}$ ring. This strain appears in all four independent $\mathrm{Cp}$ rings and reflects a steric crowding between the $-\mathrm{Si}\left(\mathrm{CH}_{3}\right)_{3}$ group and the rest of the molecule: from the affected $\mathrm{CH}_{3}$ group, $\mathrm{C}-\mathrm{C}$ distances are 3.81 [4] $\AA$ to a methyl $\mathrm{C}$ atom on the $\mathrm{Si}$ bridge $(\mathrm{Cl}$ or $\mathrm{C} 2)$, $4.02[5] \AA$ to a methyl $\mathrm{C}$ atom on the ${ }^{\mathrm{B}} \mathrm{Bu}$ group of the opposite bridge and only $3.68[3] \AA$ to a $\mathrm{Cp} \mathrm{C}$ atom in the opposite $\mathrm{Cp}$ ring. The 'radius' of a $-\mathrm{CH}_{3}$ group is taken as $2.0 \AA$; thus the first contact is $0.09 \AA$ short while the second is at just the van der Waals distance. The $3.68 \AA$ contact is short enough to imply the severe strain of bending a $\mathrm{C}-\mathrm{Si}-\mathrm{C}$ bond by $8^{\circ}$ or so.

The $\mathrm{Li}(\text { thf })_{2}^{+}$group is joined to the two $\mathrm{Cl}$ atoms of the $\mathrm{Y}$ molecule, with $\mathrm{Li}-\mathrm{Cl}$ distances averaging
$2.371[25] \AA$, almost exactly the sum of the crystal radii for $\mathrm{Li}^{+}$and $\mathrm{Cl}^{-}$and shorter than the $\mathrm{Li}-\mathrm{C}$ distance $(2.57 \AA)$ in $\mathrm{LiCl}$ (Wells, 1962). Coordination about the $\mathrm{Li}^{+}$atom is approximately tetrahedral (Fig. 1), with normal $\mathrm{Li}-\mathrm{O}$ distances $\{1.92[2] \AA$ $\}$. The thf molecules have large apparent thermal motions, indicating a moderate disorder.

This work has been supported by the USDOE Office of Basic Energy Sciences (Grant No. DEFG03-85ER113431) and by Exxon Chemicals Americas.

\section{References}

CROMER, D. T. (1974). International Tables for X-ray Crystallography, Vol. IV, pp. 149-151. Birmingham: Kynoch Press. (Present distributor Kluwer Academic Publishers, Dordrecht.)

Cromer, D. T. \& WABER, J. T. (1974). International Tables for $X$-ray Crystallography, Vol. IV, pp. 99-101. Birmingham: Kynoch Press. (Present distributor Kluwer Academic Publishers, Dordrecht.)

DuCHAMP, D. J. (1964). CRYM crystallographic computing system. Am. Crystallogr. Assoc. Meet., Bozeman, Montana. Paper B14, p. 29.

JOHNSON, C. K. (1976). ORTEPII. Report ORNL-3794, revised. Oak Ridge National Laboratory, Tennessee, USA.

Piers, W. E., Shapiro, P. J., Bunel, E. E. \& Bercaw, J. E. (1990). Synlett, 2, 74-84.

Roll, W., Brintzinger, H. H., RIEGer, B. \& ZolK, R. (1990). Angew. Chem. Int. Ed. Engl. 29, 279-280.

Wells, A. F. (1962). Structural Inorganic Chemistry, 3rd edition, p. 357. Oxford Univ. Press.

Wiesenfeldt, H., Reinmuth, A., Barsties, E., Evertz, K. \& BrINTZINGER, H. H. (1989). J. Organomet. Chem. 369, 359-370.

Acta Cryst. (1992). C48, 1776-1778

\title{
A Bis(pyrazolyl)(bipyridyl)platinum Complex
}

\author{
By William P. Schaefer, William B. Connick, Vincent M. Miskowski and Harry B. Gray \\ Division of Chemistry and Chemical Engineering* and The Beckman Institute, Mail Code 139-74, \\ California Institute of Technology, Pasadena, California 91125, USA
}

(Received 26 December 1991; accepted 11 February 1992)

\begin{abstract}
Dimethyl-2,2'-bipyridyl)bis(3,5-dimethylpyrazolium)platinum(II) 0.5-tetrahydrofuran solvate monohydrate, $\left[\mathrm{Pt}\left(\mathrm{C}_{5} \mathrm{H}_{7} \mathrm{~N}_{2}\right)_{2}\left(\mathrm{C}_{12} \mathrm{H}_{12}-\right.\right.$ $\left.\mathrm{N}_{2}\right)$ ].0.5 $\mathrm{C}_{4} \mathrm{H}_{8} \mathrm{O} . \mathrm{H}_{2} \mathrm{O}, M_{r}=623.65$, monoclinic, $P 2_{1} / n$, $a=8.625(2), b=20.593(8), c=14.451$ (4) $\AA, \beta=$ $90.32(2)^{\circ}, \quad V=2566.7(14) \AA^{3}, \quad Z=4, \quad D_{x}=$

* Contribution No. 8555 .
\end{abstract}

0108-2701/92/101776-03\$06.00
$1.61 \mathrm{~g} \mathrm{~cm}^{-3}, \quad \lambda($ Mo $K \alpha)=0.71073 \AA, \quad \mu=$ $55.50 \mathrm{~cm}^{-1}, F(000)=1232$, room temperature, $R=$ 0.0387 for 2874 reflections with $F_{o}^{2}>3 \sigma\left(F_{o}^{2}\right)$. The square-planar $\mathrm{Pt}$ complex has normal $\mathrm{Pt}-\mathrm{N}$ (bipyridyl) bonds [2.009 (8) $\AA]$ and slightly short $\mathrm{Pt}-\mathrm{N}($ pyrazolyl) bonds [1.983 (7) $\AA$ ]. The ligand molecules have normal distances and angles; the planes of the pyrazolyl ligands are twisted by about

(C) 1992 International Union of Crystallography 
$60^{\circ}$ to the bipyridyl-Pt plane, with the closest contacts between the pyrazolyls being $\sim 3.3 \AA(\mathrm{C} 14 \cdots \mathrm{N} 5$ and $\mathrm{C} 19 \cdots \mathrm{N} 3)$.

Introduction. In the course of our work on platinum(II) pyrazolyl bridged dimers, we have prepared a series of bis(pyrazolyl)(bipyridyl)platinum(II) monomers. These complexes have emissive states of MLCT or $\pi-\pi^{*}$ character, depending on the substituents on the pyrazole ring. Here we report the structure of $\left(4,4^{\prime}\right.$-dimethyl-2,2'-bipyridyl)bis(3,5-dimethylpyrazolium)platinum(II), a derivative synthesized according to the literature method for the unmethylated analog (Minghetti, Banditelli \& Bonati, 1979).

Experimental. A yellow needle, $0.07 \times 0.07 \times$ $0.36 \mathrm{~mm}$, crystal was used for data collection on a CAD-4 diffractometer with $\omega$ scans. 25 reflections with $14<2 \theta<16^{\circ}$ were used for determination of the unit cell. An absorption correction based on $\psi$ scans of six reflections, with relative transmissions from 0.882 to 1.000 , was applied to the data collected: $(\sin \theta / \lambda)_{\max }=0.59 \AA^{-1} ; h$ from -10 to $10, k$ from -24 to $24, l$ from 0 to 17 . Three standard reflections $(204,2 \overline{5} \overline{2}, 2 \overline{3} 3)$ showed no variations greater than those predicted by counting statistics. 9834 reflections were measured, of which 4501 were independent; goodness of fit for merging 4368 multiples was $0.974 ; R_{\text {merge }}=0.041$ for 3377 duplicates. All reflections were used in solution and refinement of the structure. The $\mathrm{Pt}$ atom was located from a Patterson map, while the remaining heavy atoms were found by successive structure factor-Fourier calculations. $F^{2}$ values were used in the least-squares refinement. $\mathrm{H}$ atoms were positioned by calculation $(\mathrm{C}-\mathrm{H}=0.95 \AA)$ and not refined. Coordinates and anisotropic displacement parameters of all atoms in the $\mathrm{Pt}$ molecule and the water $\mathrm{O}$ atom, plus a scale factor were refined. For 3933 reflections with $F_{o}^{2}>0$, $R($ on $F)=0.062, w R\left(\right.$ on $\left.F^{2}\right)=0.0078 ; S=1.49$ for 271 parameters and 4501 reflections. Weights were taken as $1 / \sigma^{2}\left(F_{o}^{2}\right)$; variances $\left[\sigma^{2}\left(F_{o}^{2}\right)\right]$ were derived from counting statistics plus an additional term, $(0.014 I)^{2}$; variances of the merged data by propagation of e.s.d. plus another additional term, $(0.014 \bar{I})^{2}$. $(\Delta / \sigma)_{\max }=0.01$. The final difference map showed one peak of $2.2 \mathrm{e} \AA^{-3}, 1.8 \AA$ from $\mathrm{Cl} 18$ and $\mathrm{Cl} 9$, with the next highest of $1.4 \mathrm{e} \AA^{-3}$ near the $\mathrm{Pt}$ atom; the largest negative peak, -1.9 e $\AA^{-3}$, was near C23 of the disordered thf. Atomic scattering factors and dispersion corrections were taken from Cromer \& Waber (1974) and Cromer (1974). Computer programs used were those of the CRYM crystallographic computing system (Duchamp, 1964) and ORTEP (Johnson, 1976). Final refined parameters of
Table 1. Final refined positional parameters $\left(\times 10^{4}\right)$ and equivalent isotropic displacement parameters $\left(\AA^{2} \times 10^{4}\right)$

$$
U_{\mathrm{eq}}=(1 / 3) \sum_{i} \sum_{j} U_{i j} a_{i}^{*} a_{j}^{*} \mathbf{a}_{i} \cdot \mathbf{a}_{j}
$$

$\begin{array}{lcccc} & x & y & z & U_{\text {eq }} \\ \text { Pt } & 2451(.4) & 1366(.2) & 3618(.3) & 372(1) \\ \text { N1 } & 1470(8) & 1091(3) & 4821(5) & 396(18) \\ \text { C1 } & 540(10) & 1446(5) & 5346(7) & 491(24) \\ \text { C2 } & -19(11) & 1231(5) & 6192(7) & 579(29) \\ \text { C3 } & 380(11) & 620(5) & 6506(7) & 519(29) \\ \text { C4 } & -198(14) & 363(6) & 7413(8) & 818(38) \\ \text { C5 } & 1326(11) & 243(4) & 5948(7) & 486(25) \\ \text { C6 } & 1867(9) & 480(4) & 5124(7) & 393(22) \\ \text { C7 } & 2904(9) & 129(4) & 4492(7) & 412(24) \\ \text { C8 } & 3346(11) & -506(4) & 4646(7) & 495(25) \\ \text { C9 } & 4327(11) & -804(5) & 4013(8) & 537(27) \\ \text { C10 } & 4760(14) & -1510(5) & 4131(9) & 810(39) \\ \text { C11 } & 4858(11) & -452(5) & 3263(8) & 539(27) \\ \text { C12 } & 4342(11) & 194(5) & 3147(7) & 488(25) \\ \text { N2 } & 3379(8) & 481(3) & 3747(5) & 384(18) \\ \text { N3 } & 1428(8) & 2224(3) & 3584(5) & 396(19) \\ \text { C13 } & 2057(10) & 2817(4) & 3578(7) & 445(24) \\ \text { C14 } & 3747(11) & 2936(5) & 3683(8) & 615(29) \\ \text { C15 } & 872(12) & 3267(5) & 3496(7) & 567(28) \\ \text { C16 } & -471(10) & 2901(5) & 3445(7) & 501(26) \\ \text { C17 } & -2140(12) & 3126(5) & 3354(8) & 735(34) \\ \text { N4 } & -161(8) & 2272(4) & 3502(5) & 454(21) \\ \text { N5 } & 3488(8) & 1581(3) & 2430(5) & 413(19) \\ \text { C18 } & 2854(11) & 1740(5) & 1615(7) & 487(26) \\ \text { C19 } & 1160(12) & 1696(6) & 1420(8) & 709(34) \\ \text { C20 } & 4045(12) & 1901(5) & 1020(7) & 589(30) \\ \text { C21 } & 5428(11) & 1837(5) & 1529(7) & 498(26) \\ \text { C22 } & 7058(12) & 1937(6) & 1233(8) & 805(38) \\ \text { N6 } & 5087(8) & 1639(4) & 2389(6) & 489(21) \\ \text { W1 } & 7648(8) & 1255(3) & 3509(6) & 901(23)\end{array}$

the atoms are listed in Table $1 .^{*}$ The tetrahydrofuran molecule is located near a center of symmetry and its parameters could not be refined; an idealized thf molecule was positioned based on difference maps.

We collected data for this compound with a crystal that had $\beta=90.14^{\circ}$, solved and refined the structure, but large peaks in the difference map and distorted geometry in pyrazolyl ligand 2 caused us to conclude that our crystal was bad. The results reported here are based on data from a crystal that showed no sign of any twinning or deformity; still, the large positive peak in the difference map is near where the worst one was for the first crystal.

Discussion. A drawing of the molecule including the numbering system is shown in Fig. 1, and Table 2 gives distances and angles in the molecule. The packing is shown in Fig. 2. The $\mathrm{Pt}-\mathrm{N}$ distances to the bipyridyl $\mathrm{N}$ atoms are equal at 2.009 (13) $\AA$, and to the pyrazolyl $\mathrm{N}$ atoms at 1.983 (11) $\AA$. Distances and angles in the ligand atoms are normal, with $\mathrm{C}-\mathrm{CH}_{3}$ bonds being a little short, especially in the pyrazolyl

\footnotetext{
* Lists of assigned $\mathrm{H}$-atom parameters, anisotropic displacement parameters, complete distances and angles, and observed and calculated structure factors have been deposited with the British Library Document Supply Centre as Supplementary Publication No. SUP 55183 (25 pp.). Copies may be obtained through The Technical Editor, International Union of Crystallography, 5 Abbey Square, Chester $\mathrm{CH} 1$ 2HU, England. [CIF reference: HH0621]
} 
ligands $[\mathrm{C} 18-\mathrm{C} 19=1.449$ (14) $\AA$ is the shortest]. The pyrazolyl ligands are twisted out of the $\mathrm{Pt}-$ bipyridyl plane by $64(3)^{\circ}$ each. This orientation is comparable to other cis-bis(nitrogen heterocycle) platinum(II) systems $\left\{41.7^{\circ}\right.$ for $c$ is- $[\mathrm{Pt}(N$-methylimidazole) ${ }_{2} \mathrm{Cl}_{2}$ ] (Graves, Hodgson, van Kralingen \& Reedijk, 1978), and 55.3 and $73.2^{\circ}$ for cisPt(pyrazole) $\left.{ }_{2} \mathrm{Cl}_{2}\right]$ (Cinellu, Stoccoro, Minghetti, Bandini, Banditelli \& Bovio, 1989)\}. There are short distances between N3 and C19 [3.32 (1) $\AA$ ] and N5 and $\mathrm{C} 14$ [3.33 (1) $\AA$ ]. The $\mathrm{H}$ atoms on $\mathrm{C} 14$ and $\mathrm{C} 19$ show up as two sets of three $\mathrm{H}$ atoms each in the plane where they are expected, but none of them

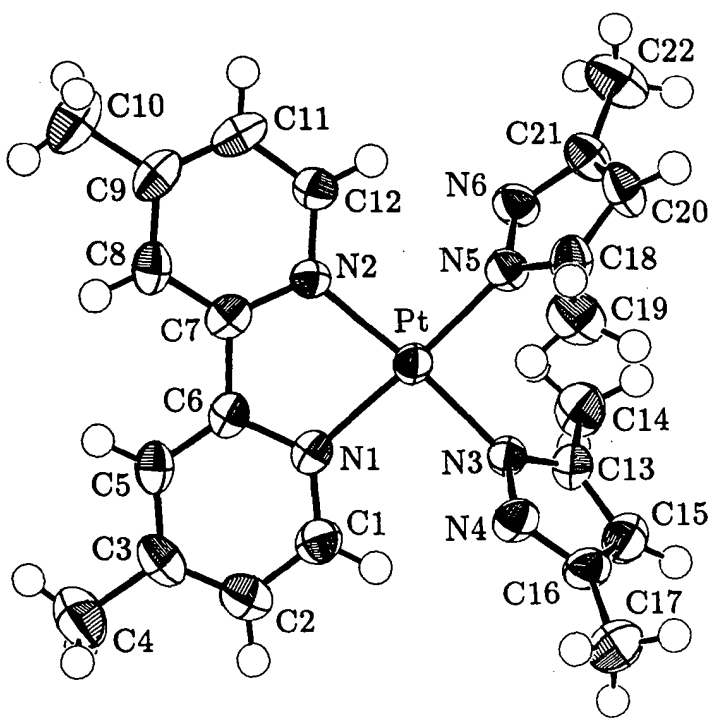

Fig. 1. An ORTEPII (Johnson, 1976) drawing of the molecule showing the numbering system. Heavy atoms are shown as $50 \%$ probability ellipsoids, $\mathrm{H}$ atoms as spheres of arbitrary size.

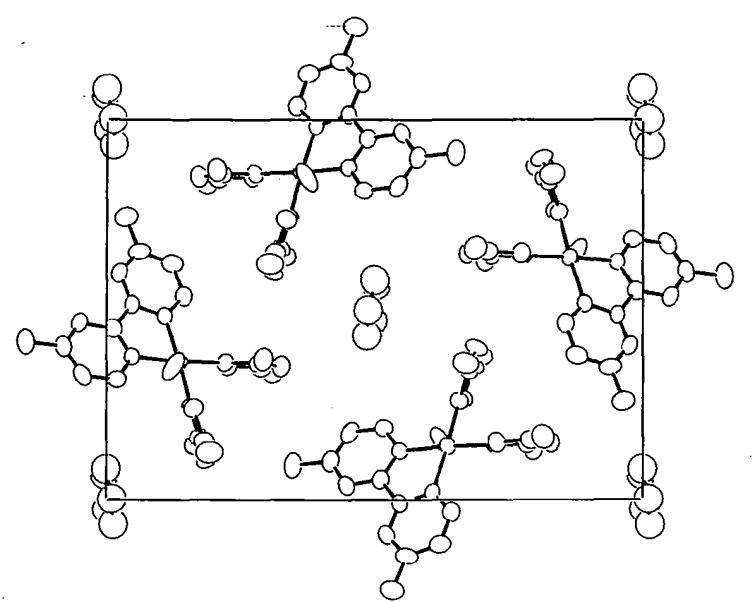

Fig. 2. An ORTEPII (Johnson, 1976) projection down the $a$ axis, with $50 \%$ probability ellipsoids. The contents of one unit cell (not including $\mathrm{H}$ atoms) are shown, plus three additional thf molecules. Only one molecular orientation is shown at each thf site.
Table 2. Distances $(\AA)$ and angles $\left(^{\circ}\right)$

$\begin{array}{llll}\mathrm{Pt}-\mathrm{N} 1 & 2.018(7) & \mathrm{C} 11-\mathrm{C} 12 & 1.412(14) \\ \mathrm{Pt}-\mathrm{N} 2 & 2.000(7) & \mathrm{C} 12-\mathrm{N} 2 & 1.341(12) \\ \mathrm{Pt}-\mathrm{N} 3 & 1.975(7) & \mathrm{N} 3-\mathrm{C} 13 & 1.337(11) \\ \mathrm{Pt}-\mathrm{N} 5 & 1.990(7) & \mathrm{N} 3-\mathrm{N} 4 & 1.379(10) \\ \mathrm{N} 1-\mathrm{C} 1 & 1.327(12) & \mathrm{C} 13-\mathrm{C} 14 & 1.485(13) \\ \mathrm{N} 1-\mathrm{C} 6 & 1.376(11) & \mathrm{C} 13-\mathrm{C} 15 & 1.384(13) \\ \mathrm{Cl}-\mathrm{C} 2 & 1.389(14) & \mathrm{C} 15-\mathrm{C} 16 & 1.383(14) \\ \mathrm{C} 2-\mathrm{C} 3 & 1.381(14) & \mathrm{C} 16-\mathrm{C} 17 & 1.517(15) \\ \mathrm{C} 3-\mathrm{C} 4 & 1.501(15) & \mathrm{Cl} 1-\mathrm{N} 4 & 1.326(12) \\ \mathrm{C} 3-\mathrm{C5} & 1.388(14) & \mathrm{N} 5-\mathrm{C} 18 & 1.338(12) \\ \mathrm{C} 5 \mathrm{C} 6 & 1.371(13) & \mathrm{N} 5-\mathrm{N} 6 & 1.386(10) \\ \mathrm{C} 6-\mathrm{C} 7 & 1.471(12) & \mathrm{C} 18-\mathrm{C} 19 & 1.489(14) \\ \mathrm{C} 7-\mathrm{C} 8 & 1.379(13) & \mathrm{C} 18-\mathrm{C} 20 & 1.383(14) \\ \mathrm{C} 7-\mathrm{N} 2 & 1.363(11) & \mathrm{C} 20-\mathrm{C} 21 & 1.404(14) \\ \mathrm{C} 8-\mathrm{C} 9 & 1.391(14) & \mathrm{C} 21-\mathrm{C} 22 & 1.486(15) \\ \mathrm{C} 9 \mathrm{C} 10 & 1.512(15) & \mathrm{C} 21-\mathrm{N} 6 & 1.342(12) \\ \mathrm{C}-\mathrm{C} 11 & 1.384(14) & & \end{array}$

$\begin{array}{lrll}\mathrm{N} 1-\mathrm{Pt}-\mathrm{N} 2 & 80.4(3) & \mathrm{C} 11-\mathrm{C} 9-\mathrm{C} 10 & 120.7(9) \\ \mathrm{N} 1-\mathrm{P}-\mathrm{N} 3 & 94.8(3) & \mathrm{C} 12-\mathrm{C} 11-\mathrm{C} 9 & 118.8(9) \\ \mathrm{N} 1-\mathrm{Pt}-\mathrm{N} 5 & 176.2(3) & \mathrm{N} 2-\mathrm{C} 12-\mathrm{C} 11 & 122.2(8) \\ \mathrm{N} 2-\mathrm{Pt}-\mathrm{N} 3 & 175.2(3) & \mathrm{C} 12-\mathrm{N} 2-\mathrm{C} 7 & 117.9(7) \\ \mathrm{N} 2-\mathrm{Pt}-\mathrm{N} 5 & 95.8(3) & \mathrm{N} 4-\mathrm{N} 3-\mathrm{C} 13 & 109.7(7) \\ \mathrm{N} 3-\mathrm{Pt}-\mathrm{N} 5 & 89.0(3) & \mathrm{C} 14-\mathrm{C} 13-\mathrm{N} 3 & 123.2(8) \\ \mathrm{C} 6-\mathrm{N} 1-\mathrm{Cl} & 118.2(7) & \mathrm{C} 15-\mathrm{C} 13-\mathrm{N} 3 & 108.2(8) \\ \mathrm{C} 2-\mathrm{C} 1-\mathrm{N} 1 & 122.8(9) & \mathrm{C} 15-\mathrm{C} 13-\mathrm{Cl} & 128.6(9) \\ \mathrm{C} 3-\mathrm{C} 2-\mathrm{C} 1 & 119.6(9) & \mathrm{C1}-\mathrm{C} 15-\mathrm{C} 13 & 105.0(9) \\ \mathrm{C} 4-\mathrm{C} 3-\mathrm{C} 2 & 112.7(9) & \mathrm{C} 17-\mathrm{C} 16-\mathrm{C} 15 & 129.2(9) \\ \mathrm{C} 5-\mathrm{C} 3-\mathrm{C} 2 & 117.7(9) & \mathrm{N} 4-\mathrm{C} 16-\mathrm{C} 15 & 111.2(8) \\ \mathrm{C} 5-\mathrm{C} 3-\mathrm{C} 4 & 120.7(9) & \mathrm{N} 4-\mathrm{C} 16-\mathrm{C} 17 & 119.6(8) \\ \mathrm{C} 6-\mathrm{C} 5-\mathrm{C} 3 & 120.7(9) & \mathrm{C} 16-\mathrm{N} 4-\mathrm{N} 3 & 105.9(7) \\ \mathrm{C} 5-\mathrm{C} 6-\mathrm{N} 1 & 121.1(8) & \mathrm{N} 6-\mathrm{N} 5-\mathrm{C} 18 & 110.0(7) \\ \mathrm{C} 7-\mathrm{C} 6-\mathrm{N} 1 & 113.8(7) & \mathrm{C} 19-\mathrm{C} 18-\mathrm{N} 5 & 123.2(8) \\ \mathrm{C} 7-\mathrm{C} 6-\mathrm{C} 5 & 125.2(8) & \mathrm{C} 20-\mathrm{C} 18-\mathrm{N} 5 & 107.7(8) \\ \mathrm{C} 8-\mathrm{C} 7-\mathrm{C} 6 & 122.3(8) & \mathrm{C} 20-\mathrm{C} 18-\mathrm{C} 19 & 128.9(9) \\ \mathrm{N} 2-\mathrm{C} 7-\mathrm{C} 6 & 114.6(7) & \mathrm{C} 21-\mathrm{C} 20-\mathrm{C} 18 & 106.5(9) \\ \mathrm{N} 2-\mathrm{C} 7-\mathrm{C} 8 & 123.2(8) & \mathrm{C} 22-\mathrm{C} 21-\mathrm{C} 20 & 129.7(9) \\ \mathrm{C} 9-\mathrm{C} 8-\mathrm{C} 7 & 118.7(9) & \mathrm{N} 6-\mathrm{C} 21-\mathrm{C} 20 & 108.9(8) \\ \mathrm{C} 10-\mathrm{C} 9-\mathrm{C} 8 & 120.1(9) & \mathrm{N} 6-\mathrm{C} 21-\mathrm{C} 22 & 121.4(9) \\ \mathrm{C} 11-\mathrm{C} 9-\mathrm{C} 8 & 119.3(9) & \mathrm{C} 21-\mathrm{N} 6-\mathrm{N} 5 & 106.8(7) \\ \end{array}$

points toward the close $\mathrm{N}$ atom. The water molecule is 2.82 (1) $\AA$ from N4, indicating a hydrogen bond between them; there are also contacts between the water molecule and $\mathrm{C} 5$ and $\mathrm{C} 8$ in a different molecule [3.30 (1) and 3.20 (1) $\AA$ ]. The $\mathrm{Pt}-\mathrm{O}$ (water) distance $[4.492(7) \AA]$ and all other intermolecular distances are at van der Waals distances or greater.

This research was supported by the Office of Naval Research.

\section{References}

Cinellu, M. A., Stoccoro, S., Minghett, G., Bandin, A. L., Banditelli, G. \& Bovio, B. (1989). J. Org. Chem. 372, 311-325.

CROMER, D. T. (1974). International Tables for X-ray Crystallography, Vol. IV, pp. 149-151. Birmingham: Kynoch Press. (Present distributor Kluwer Academic Publishers, Dordrecht.)

CROMER, D. T. \& WABER, J. T. (1974). International Tables for $X$-ray Crystallography, Vol. IV, pp. 99-101. Birmingham: Kynoch Press. (Present distributor Kluwer Academic Publishers, Dordrecht.)

DUCHAMP, D. J. (1964). CRYM crystallographic computing system. Am. Crystallogr. Assoc. Meet., Bozeman, Montana. Paper B14, p. 29.

Graves, B. J., Hodgson, D. J., van Kralingen, C. G. \& REEDIJK, J. (1978). Inorg. Chem. 17, 3007-3011.

JoHNSON, C. K. (1976). ORTEPII. Report ORNL-3794, third revision. Oak Ridge National Laboratory, Tennessee, USA.

Minghetti, G., Banditelli, G. \& Bonati, F. (1979). J. Chem. Soc. Dalton Trans. pp. 1851-1856. 